\title{
Global from the Start: The Characteristics of Born-Global Firms in the Technology Sector
}

\author{
Stoyan Tanev
}

\author{
"Born-global companies merit much more attention than") \\ they are receiving, as their growth strategies could \\ provide lessons for many other organizations. \\ Alina Kudina, George S. Yip, and Harry G. Barkema \\ "Born Global”, Business Strategy Review, 2008
}

\begin{abstract}
This article provides insights from recent research on firms that are "born global". A bornglobal firm is a venture launched to exploit a global niche from the first day of its operations. The insights in this article are relevant to technology entrepreneurs and top management teams of new technology firms. After discussing various definitions for the term "born global" and identifying the main characteristics of born-global firms, this article lists a few salient characteristics of firms that are born global in the technology sector. The article concludes by identifying opportunities for future research.
\end{abstract}

\section{Introduction}

The "born global" label originated with Michael Rennie (1993; tinyurl.com/7d6aa22), who studied firms established with the capability to compete internationally and coordinate resources across countries (Jones et al., 2011; tinyurl.com/7mbjjzz). Research on born-global firms focuses on how to launch and grow a small firm to satisfy the needs of customers in a global niche (Cavusgil and Knight, 2009: tinyurl.com/74th3bb; Knight and Cavusgil, 1996: tinyurl.com/7hxs7l2; Madsen and Servais, 1997: tiny url.com/82pgrhj). The internationalization of businesses has become a pervasive phenomenon, which underscores the importance of the born-global concept and the need for researchers and practitioners to understand the factors that influence the success of bornglobal firms.

In the international business literature, firms that internationalize early in their life cycle are also referred to as "global startups" (Oviatt and McDougall, 1995; tinyurl .com/6w6v8cj), "instant internationals" (Fillis, 2001; tinyurl .com/7e8dqb3), and "international new ventures" (Oviatt and McDougall, 1994; tinyurl.com/79eye8t). Although many firms target global niches and develop a global presence within one or two years of their founding (Autio et al., 2000: tinyurl.com/7plvc5d; McDougall and Oviatt, 2000: tiny url.com/745yv3v; Rennie, 1993: tinyurl.com/7d6aa22), this does not mean they fit the definition of "born global".

For the purpose of this paper, a true born-global firm is a new venture that acts to satisfy a global niche from day one. While various definitions of born-global firms have been proposed (Jones et al., 2011; tinyurl.com/7mbjjzz), this definition of born-global firms fits best with the entrepreneurship literature and is consistent with the definition advanced by Moen, Sørheim, and Erikson (2008; tinyurl.com/82r2j4k). This definition focuses on the creation of new ventures that are international by design and not by emergence. Thus, the unit of analysis is a startup that is born global, excluding firms that have simply grown to be global after being a domestic firm for a period of time.

The remainder of this article is organized into four sections. The next section describes the distinctive characteristics of born-global firms. Then, the conditions that enable a technology firm to go global are identified, the 


\section{The Characteristics of Born-Global Firms in the Technology Sector}

\section{Stoyan Tanev}

importance of business ecosystems to the growth of born-global firms is highlighted, and a set of research questions is advanced. The last section provides the conclusions.

\section{Distinctive Characteristics of Born-Global Firms}

Born-global firms possess the following distinctive characteristics:

\section{High activity in international markets from or near the founding}

Born-global firms begin exporting their products or services within a couple of years after their founding and may export a quarter or more of their total production. Most of them advance through subsequent stages of internationalization, collaboration with foreign partners, or undertaking of direct foreign investment. Findings from Denmark and Australia show that, although bornglobal firms are presumed to have the intent to internationalize from inception; internationalization is not necessarily an objective in the founding process (Rasmussen et al., 2001; tinyurl.com/7u8pj4l). The decision to engage the firm into a systematic internationalization process is usually determined by the nature of the new firm; the type of technology that is being developed or the firm's specialization within the specific industry sector, value chain, or market (Jones et al., 2011; tinyurl.com/7mbjjzz). Other studies from Norway and France show slightly different results, indicating that, although the specific market situation is important, the extent to which a firm is a born global rather than a "born local" or a "late global" depends on the firm's own early decisions (Moen, 2002; tinyurl.com/7yegguu). Similar findings were reported in Sweden and Finland, where the founder's vision at the time of the incorporation was found to be a key factor for a firm's early internationalization patterns (Gabrielsson and Pelkonen, 2008; tinyurl.com/6ot26js).

\section{Limited financial and tangible resources}

Born-global firms tend to be relatively small and have far fewer financial, human, and tangible resources as compared to large multinational enterprises that have been considered as dominant in global trade and investment.

\section{Present across most industries}

Many born-global firms are technology firms. However, recent evidence suggests that the born global phenomenon is widely spread beyond the technology sector (Moen, 2002: tinyurl.com/7yegguu; Rennie, 1993: tinyurl.com/7d6aa22). For example, in Denmark, Madsen, and Servais (1997; tinyurl.com/82pgrhj) have found bornglobal firms in industries such as metal fabrication, furniture, processed food, and consumer products.

\section{Managers have a strong international outlook and in- ternational entrepreneurial orientation}

The managers of born-global firms do not see foreign markets as a mere addition to their domestic markets. They possess a strong entrepreneurial mindset. They proactively and aggressively compete in international markets, they take risks, and innovate. Findings from the United States, the United Kingdom, Australia, Canada, Ireland, and New Zealand highlight the importance of the combined role of the creativity, knowledge, and resourcefulness of the top management team and not just of the personal qualities of a single entrepreneur. The skills of top management teams have been found important for a more dynamic form of internationalization, particularly in the knowledge-based sectors (Johnson, 2004: tinyurl.com/7ylm49z; Andersson and Evangelista, 2006: tinyurl.com/6wm49re; Loane et al., 2007; tinyurl.com/7hdohoc).

\section{Emphasis on differentiation strategy}

Born-global firms tend to adopt differentiation strategies by developing differentiated designs and highly distinctive products that target niche markets, which may be too small for the tastes of larger firms. The focus is on stimulating customer loyalty by uniquely meeting particular needs. "People and firms increasingly demand specialized and customized products, and niche markets have become an important source of opportunities for small firms" (Cavusgil and Knight, 2009; tinyurl.com/74th3bb).

\section{Emphasis on superior product quality}

Born-global firms are often at the leading technological edge of their industry or product category. They are founded to exploit business opportunities based on the development of new products or services that are better designed and higher quality than competitors' offerings. Typically, these firms do not operate in "commodity" markets (Cavusgil and Knight, 2009; tinyurl.com/74th3bb).

\section{Leveraging advanced information and communica- tions technology (ICT)}

Many born-global firms leverage ICT to segment customers into narrow global-market niches and skillfully serve highly specialized buyer needs. ICT allows them to process information efficiently and communicate with partners and customers worldwide at practically zero cost (Cavusgil and Knight, 2009; tinyurl.com/74th3bb). 


\section{The Characteristics of Born-Global Firms in the Technology Sector}

\section{Stoyan Tanev}

\section{Using external, independent intermediaries for distri-} bution in foreign markets

Most born-global firms expand internationally through exports by engaging in direct international sales or leveraging the resources of independent intermediaries located abroad. Many of them rely on external facilitators to organize international shipments. Exporting and leveraging independent intermediaries enables flexible international operations including the ability to enter or withdraw from foreign markets relatively quickly and easily. More experienced born-global firms appear to adopt additional strategies, such as joint ventures and foreign direct investment (Cavusgil and Knight, 2009; tinyurl.com/74th3bb).

\section{The Specifics of Technology Firms}

The majority of born-global firms are technology companies. A research study based on a comprehensive analysis of 12 technology firms in England formulated a number of conditions for newly created technology firms considering early, rapid globalization (Kudina et al., 2008; tinyurl.com/83c2qdz). Although these conditions were developed in a very specific context, it is worth summarizing them here:

1. The market in the home country is not large enough to support the scale at which the firm needs to operate.

2. Most of the firm's potential customers are foreign, multinational firms.

3. Many of the firm's potential customers have overseas operations where they will use the firm's products or services.

4. The firm operates in a knowledge-intensive or hightechnology sector.

5. Having the most technically advanced offering in the world is key to the firm's competitive advantage.

6. The firm's product or service category faces few trade barriers.

7. The firm's product or service has high value relative to its transportation and other logistics costs.

8. Customer needs and tastes are fairly standard across the firm's potential country-markets.
9. The firm's product or service has significant firstmover advantages or network effects.

10. The firm's major competitors have already internationalized or will internationalize soon.

11. The firm has key managers who are experienced in international business.

\section{The Importance of Ecosystems}

Researchers have identified a number of organizational capabilities that enable internationalization and increase the international performance of born-global firms. Kudina, Yip, and Barkema (2008; tinyurl.com/83c2qdz) attribute the success of technology firms that are born global to their effective use of three types of ecosystems:

1. The first type of ecosystem is anchored around universities and firms operating in the same industry as the focal firm. Being part of such ecosystems results in a flow of technological knowledge, experienced people, and contacts with local venture capitalists that benefit the focal firm. The knowledge and expertise developed within such ecosystems provide a global competitive advantage.

2. The second type of ecosystem establishes and strengthens relationships between the local operations of firms and their foreign sales subsidiaries. Such networks are important sources of knowledge from experts that are spread out internationally. The ecosystem facilitates direct contacts between engineers and clients to satisfy the specific needs of clients and provides a mechanism for winning additional business.

3 . The third type of ecosystem is anchored around foreign sales subsidiaries and local clients that are important for high-quality service. Such ecosystems involve customers and provide highly relevant information about client needs in relation to product development. These contacts help firms to obtain technological knowledge from the client or through the client's business partners that they would otherwise have to develop themselves.

The success of a firm is conditional on its ability to create an ecosystem of firms beyond its clients. The ecosystem comprises firms in the industry in which it has clients, as well as firms in many other related industries. Such an arrangement helps the firm to secure clients in a more systematic way as part of its ecosystem. 


\section{The Characteristics of Born-Global Firms in the Technology Sector}

\section{Stoyan Tanev}

\section{Research Questions}

The research on born-global firms is growing. There are many relevant research questions that should be addressed in future studies. This section builds on the research questions that have been discussed in the literature (Cavusgil and Knight, 2009; tinyurl.com/74th3bb). Suggested research questions include:

1. What barriers inhibit technology firms from being born global?

2. What factors contribute to the early success of bornglobal firms even in light of their limited access to resources?

3. What are the main advantages associated with internationalization at an early stage of the life cycle of a technology company? What is the nature of these advantages and how could they be developed?

4. How can design principles help launch and grow born-global technology firms?

5. How do resource-poor technology companies reconcile the costly needs for product customization in unique foreign markets with the need to achieve economies through product standardization? How can customer co-creation capabilities and business models help new firms deal with the high costs of customization?

6. Does early internationalization also occur among firms that specialize in technology-driven services? If so, how do they differ from manufacturers? How can product-enabled services help firms to differentiate themselves and compete in foreign markets?

7. What is the role of ecosystems in launching and growing technology firms that are born global? How do ecosystems advance internationalization goals of technology companies? What types of network contacts are most beneficial?

8. What proportion of born-global technology firms become large, successful firms? How many merge with other firms or become acquired by larger ones? Do born-global firms go out of business at the same rate as firms that were not born global? How do born-global companies grow?

9. Is ownership of born-global firms significantly different from ownership of firms that were not born global?

\section{Conclusion}

The main objective of this article was to discuss the characteristics of born-global firms. The literature on born-global firms has developed separately from the technology entrepreneurship literature. The various definitions of born-global firms do not enable linking research on born-global firms and the theory of the firm or entrepreneurship theory. This fact provides valuable opportunities for future research.

If technology firms that are born global are more successful than technology firms that are not born global, we should focus on defining design principles that incorporate key attributes of born-global firms and use these design principles to launch and grow technology companies. This article is a call to first empirically validate that born-global firms are more successful than firms that were not born global and then identify the design principles that can be used to design technology startups.

\section{About the Author}

Stoyan Tanev is an Associate Professor in the Institute of Technology and Innovation and member of the Integrative Innovation Management (I2M) Research Unit at the University of Southern Denmark, Odense, Denmark. He is also Adjunct Professor in the Department of Systems and Computer Engineering at Carleton University in Ottawa, Canada, where he was previously a faculty member in the Technology Innovation Management Program. He has an MSc and PhD in Physics (jointly by the University of Sofia, Bulgaria, and the University Pierre and Marie Curie, Paris, France), an MEng in Technology Management (Carleton University, Canada), and a MA (University of Sherbrooke, Canada). His main research interests are in the fields of technology innovation management and value co-creation in technology-driven businesses. Dr. Tanev is also on the Review Board of the Technology Innovation Management Review. 